Missio Ecclesiae
ISSN 2086-5368 (Print)
ISSN 2721-8198 (Online)
https://jurnal.i3batu.ac.id/index.php/me
Vol.9, No.1, pp. 113-131, 2020

\title{
Bolehkah Orang Kristen Di Kota Wisata Batu Bercerai?
} Erni M.C. Efruan

InstitutInjil Indonesia, erni_i3@yahoo.co.id

\section{INFO ARTIKEL}

Sejarah Artikel:

Diterima : Maret 2019

Direvisi : April 2020

Disetujui: April 2020

Dipublikasi: April 2020

Kata Kunci:

Pernikahan, Perceraian,

Markus 10:1-12.

Keywords:

Marriage, Divorce,

Markus 10:1-12.

\section{ABSTRAK}

Pada saat kini tingkat perceraian di Indonesia sangat memprihatinkan. Sebuah surat kabar harian dengan berani mengusung tema "Perceraian Darurat Di Indonesia!" Badan Kependudukan dan Keluarga Berencana Nasional (BKKBN) memperingatkan bahwa angka perceraian di Indonesia adalah yang tertinggi di Asia Pasifik. Di antara jumlah permohonan perceraian yang masuk tahun 2019 tercatat 604.997 kasus, 79 persen permohonan telah dikabulkan pengadilan. Lebih dari 479.618 pasangan menikah telah resmi bercerai. Mengejutkannya, perkara kasus perceraian yang diajukan dari pihak istri (Cerai Gugat) totalnya mencapai 355.842 kasus. Artinya penggugat cerai oleh istri sebanyak 70 persen. Sedangkan kasus perceraian yang diajukan dari pihak suami (Cerai Talak) mencapai 124.776 kasus. Di Jawa Timur, Januari hingga Mei 2016 terdapat 3.063 pengajuan kasus perceraian. Total 2.032 istri yang menuntut perceraian terhadap suaminya. Data pada Kemenag Kota Batu tercatat 300 kasus perceraian dan 300 pernikahan dini terjadi dari 1.678 perkawinan pada tahun 2018. Dengan demikian latar belakang penelitian adalah: Apakah orang Kristen di Kota Wisata Batu, Jawa Timur juga berkontribusi pada peningkatan angka perceraian di Indonesia? Bolehkah orang Kristen bercerai? Bagaimana tanggapan Yesus Kristus menurut Injil Markus 10: 1-12? Tujuan penelitian adalah menemukan jawaban Yesus dalam Injil Markus 10: 1-12 sebagai perspektif yang dapat ditimplementasikan dan antisipatif terhadap meningkatnya jumlah kasus perceraian di Kota Wisata Batu, Jawa Timur. Pendekatan terhadap topik "Bolehkah Orang Kristen Di Kota Wisata Batu, Jawa Timur Bercerai?" menggunakan Metode Deskripsi. Hasil analisis literatur menyimpulkan bahwa Yesus Kristus tidak pernah mengizinkan perceraian pasangan Kristen dengan alasan apa pun. Tidak pernah! Hasil survei lapangan menunjukkan bahwa ada kasus perceraian, tetapi tidak terdaftar di Kantor Pemerintah terkait di Kota Wisata Batu, Jawa Timur. Oleh karena itu, penyelidikan ini masih terbuka untuk penelitian lebih lanjut, mengapa ada dua kasus perceraian pada pasangan Kristen di Kota Wisata Batu, Jawa Timur, namun tidak terdaftar di Instansi Pemerintah?

\section{ABSTRACT}

Abstract: At present the divorce rate in Indonesia is very alarming. A daily newspaper with a challenge with the theme "Emergency Divorce in Indonesia!" The National Population and Family Planning Agency (BKKBN) considers the divorce rate in Indonesia to be the highest in the Asia Pacific. Of the number received in 2019 received 604,997 cases, 79 percent received were granted by the court. More than 479,618 married couples have been officially divorced. 


\begin{abstract}
Surprisingly, the case cases requested by the wife (Divorced) totaled 355,842 cases. $70 \%$ of divorced plaintiffs should have been married. While the divorce cases filed by the husband (divorce divorce) reached 124,776 cases. In East Java, from January to May 2016 there were 3,063 divorce cases filed. Total of 2,032 wives who needed divorce from the petition. Data from the Ministry of Religion in Batu saw 300 cases of divorce and 300 early marriages occur from 1,678 marriages in 2018. Thus, the background of the study is: Do Christians in Batu Tourism City, East Java also participate in research on divorce rates in Indonesia? Can Christians get divorced? What is the response of Jesus Christ according to the Gospel of Mark 10:1-12? The purpose of the research is to find answers about Jesus in the Gospel of Mark 10: 1-12 as a replicable and anticipatory perspective on a small number of divorce cases in Batu Tourism City, East Java. About "Christians in Batu Tourism City, East Java Divorced" using the Description Method. The results of the analysis of literature about Jesus Christ never allow divorce of Christian couples for any reason. Never! Field survey results show divorce, but not registered at the relevant Government Office in Batu Tourism City, East Java. Therefore, this investigation is still open for further research, research on divorce of Christian couples in Batu Tourism City, East Java, but not registered with a Government Agency?
\end{abstract}

\title{
PENDAHULUAN
}

Perceraian adalah situasi di mana antara suami dan istri telah terjadi perbedaan batin yang mengakibatkan putusnya ikatan pernikahan melalui keputusan pengadilan yang diatur dalam UU Perkawinan Pasal 38 hingga Pasal 41. KUH Perdata Pasal 207 mendefinisikan perceraian sebagai penghapusan perkawinan dengan keputusan hakim, atas permintaan salah satu pihak dalam perkawinan berdasarkan alasan yang terkandung dalam UU. Kamus Besar Bahasa Indonesia mendefinisikan, perceraian sebagai memutuskan hubungan sebagai suami dan istri, perpisahan, tidak bersatu, berhenti untuk berhubungan sebagai suami dan istri (The Compilation Team, 1997: 185). Perceraian adalah situasi di mana antara suami dan istri telah terjadi perbedaan batin yang mengakibatkan putusnya ikatan pernikahan melalui keputusan pengadilan yang diatur dalam UU Perkawinan Pasal 38 hingga Pasal 41. Subekti mendefinisikan perceraian sebagai penghapusan pernikahan melalui keputusan hakim, atau tuntutan salah satu pihak dalam pernikahan (Subekti, 1985: p. 23). Menurut Prawiroharmidjojo dan Saefuddin perceraian berbeda dengan pemutusan hubungan perkawinan setelah pemisahan meja dan tempat tidur di mana tidak ada perselisihan, bahkan ada niat baik dari suami-istri untuk mengakhiri pernikahan (1986, p. 109). Simanjuntak mengartikan perceraian sebagai akhir dari suatu pernikahan karena suatu alasan, karena keputusan hakim atas klaim dari salah satu pihak atau kedua belah pihak dalam pernikahan tersebut (Simanjuntak, 2007: p. 53). Perceraian selalu didasarkan pada perselisihan antara suami dan istri. Jadi, perceraian adalah akhir dari ikatan perkawinan melalui keputusan hakim tentang tuntutan salah satu pihak atau kedua belah pihak. Sedangkan pernikahan Kristen adalah institusi yang dibangun oleh Tuhan, sebagai hadiah, didukung oleh institusi negara (Kantor Catatan Sipil), dan suami dan istri berkesempatan untuk belajar tentang cinta dengan berbagai pilihan, konsekuensi, melayani satu sama lain, ramah dan menderita (Wright, 2010: pp. 9-10).

\section{KAJIAN LITERATUR}

Perceraian adalah jalan yang sangat mudah ditemukan di Indonesia, mulai dari berpendidikan tinggi hingga berpendidikan rendah, kondisi ekonomi yang kuat hingga tingkat ekonomi yang tidak stabil, bahkan lemah. Topik penelitian tentang "perceraian" sangat relevan karena mencerminkan konteks masyarakat di Indonesia pada umumnya. 
Ikatan pernikahan rapuh, mudah putus. Hal ini berdampak pada angka perceraian di Indonesia yang sangat memprihatinkan. Bahkan Harian "Merdeka" berani mengangkat tema "Perceraian Darurat Indonesia!" tetapi tidak banyak orang menyadari bahwa angka perceraian di Indonesia adalah salah satu yang tertinggi di dunia. Bahkan Badan Kependudukan dan Keluarga Berencana Nasional (BKKBN) tiga tahun lalu telah memperingatkan bahwa angka perceraian di Indonesia adalah yang tertinggi di Asia Pasifik. Namun tingkat keputusan suami-istri untuk bercerai tidak surut (Harian Merdeka, 20 September 2016). Data dari Pusat Penelitian dan Pengembangan Agama (Puslitbang) Kementerian Agama (Kemenag) Republik Indonesia menunjukkan peningkatan angka perceraian dan terus berlanjut selama sepuluh tahun ke depan. Data menunjukkan bahwa tingkat perceraian selama tahun 2010-2014 naik 100.000 kasus dibandingkan dengan lima tahun sebelumnya (Sripoku.com, 16 February 2017). Pada tahun 2017 terjadi peningkatan 2.047 perkara dari tahun 2016, menjadi 446.397 perkara perceraian di seluruh Indonesia. Januari hingga bulan Maret 2018 terdapat 136.825 perkara perceraian yang diputus Pengadilan Agama di seluruh Indonesia. Jika dikalkulasikan, maka setiap hari terdapat 1.537 kasus perkara perceraian di Indonesia (NET.Z, 3 Juni 2018).

Berdasarkan data yang dikutip Detikcom dari website Mahkamah Agung (MA), sebanyak 419.268 pasangan bercerai sepanjang 2018. Menurut data yang dikeluarkan oleh Badan Pengadilan Agama (Badilag) Mahkamah Agung, pada tahun 2019 sudah ada 604.997 kasus permohonan perceraian yang telah diterima dari seluruh Indonesia (Harian Detikcom, Rabu, 3 April 2019). Wakil Ketua Eksekutif Pusat Muhammadiyah, Amin Abdullah, mengatakan bahwa dari 2.000.000 pernikahan 300.000-340.000 gagal di tengah jalan (Harian Republika, 20 Januari 20, 2018). Bahkan lima ruang sidang di Pengadilan Agama, setiap hari digunakan oleh 20 hingga 25 orang yang mengikuti proses perceraian. Data lain menunjukkan bahwa 90 persen penggugat adalah perempuan atau istri (Harian Merdeka, 20 September 2016). Jadwal persidangan yang ketat di Pengadilan Agama Jakarta Selatan adalah gambaran yang lebih besar dari situasi di Indonesia (Hariaa Merdeka, 15 September 2016). Berdasarkan data yang diperoleh sejak 2009-2016 terdapat peningkatan bahwa angka perceraian mencapai 16 hingga 20 persen. Di Jakarta pada tahun 2013 terdapat 8.837 kasus, pada tahun 2014 ditemukan 9.731 kasus dan pada tahun 2015 meningkat menjadi 10.359 kasus (Harian Business, 20 Mei 2018).

Provinsi Jawa Barat berada di peringkat ketiga. Pada tahun 2013 tingkat perceraian berjumlah 62.184 kasus, peningkatan yang signifikan menjadi 67.129 kasus pada 2014, dengan total 70.519 kasus pada 2015 dan September 2016 telah mencapai 39.350 kasus (Harian Jawa Pos, 16 Juni 2016).

Provinsi Jawa Tengah adalah wilayah dengan tingkat perceraian tertinggi kedua di Indonesia. Total tingkat perceraian pada 2013 adalah 68.202, kemudian 70.037 kasus pada 2014. Tahun berikutnya, 2015 naik menjadi 71.774, dan pada September 2016 terdapat 40.850 kasus (Harian Jawa Pos, 16 Juni 2016).

Jawa Timur adalah Provinsi dengan tingkat perceraian tertinggi di Indonesia (Harian Republika, 3 Oktober 2016). Provinsi Jawa Timur merupakan penyumbang angka perceraian terbesar di Indonesia, yang mencapai 47 persen atau sekitar 90.000 pasangan, bahkan Harian Malang Times mengusung Topik: "Angka Perceraian di Jawa Timur Tertinggi se Indonesia" (Malang Times.com, 20 Maet 2016). Hampir setengah dari kasus perceraian di Indonesia berada di Jawa Timur (Harian Kompas, 20 Maret 2016). Gubernur Jawa Timur, Khofifah Indar Parawansa mengungkapkan angka perceraian Jawa Timur menempati posisi tertinggi dibandingkan Jawa Tengah maupun Jawa Barat (Antara, Senin, 16 September 2019). Data tersebut di atas terus mengalami peningkatan. 
Menurut data Badan Pengadilan Agama, perkara perceraian tertinggi di seluruh Indonesia berada di Surabaya, Jawa Timur yang mencapai 136.261 kasus. $^{1}$ Angka perceraian di Surabaya mendeskripsikan tren peningkatan. Mengacu pada data Pengadilan Agama Kelas IA Surabaya, sepanjang tahun 2018 terdapat 5.235 kasus perceraian. Terjadi peningkatan 363 kasus perceraian dibandingkan tahun sebelumnya. Pada tahun 2017, jumlah perceraian di Surabaya mencapai angka 4.872 perkara. Secara persentase kenaikan angka perceraian pada tahun 2018 dibandingkan tahun sebelumnya hanya 7,45 persen, namun mendominasi perkara yang ditangani Pengadilan Agama Kelas IA Surabaya. Selama satu tahun total kasus yang masuk ke Pengadilan Agama berjumlah 8.746 kasus, di dalamnya termasuk 5.235 kasus perceraian. Jadi, hampir 70 persen kasus perceraian tersebut merupakan gugatan dari pihak perempuan (JPNN.com, 3 Februari 2019).

Wakil Gubernur Jawa Timur Saifullah Yusuf menegaskan bahwa di Jawa Timur tidak kurang dari 500.000 pasangan menikah setiap tahun, tetapi berdasarkan data dari Pengadilan Agama ada 90.000 pasangan yang bercerai setiap tahun. Bahkan kasus gugatan cerai sebagian besar terjadi di kabupaten, termasuk Kabupaten Malang, di mana Kota Wisata Batu termasuk di dalamnya. ${ }^{2}$ Tingkat perceraian di Pengadilan Agama Kota Malang, Jawa Timur, pada semester pertama tahun 2013 mengalami peningkatan yang signifikan (Harian Berita Satu, 6 Juli 2013). Pengadilan Agama Mahkamah Agung (Badilag) mencatat bahwa pada tahun 2013 tingkat perceraian di Jawa Timur adalah 83.201 kasus, pada tahun 2014 naik menjadi 87.473. Data tahun 2014 tertulis 2.617 pasangan yang mengajukan cerai, didominasi oleh usia 35-40 tahun (Antara News, 9 April 2015). Kasus gugatan cerai yang telah diputuskan oleh pengadilan dan memiliki kekuatan hukum permanen 1.851 kasus (Harian Suara Pembaruan, 10 Desember 2014). Meskipun pada 2015 turun menjadi 87.241, tetapi pada September 2016 tingkat perceraian di Jawa Timur telah mencapai 51.000 kasus (Business Daily, 20 Mei 2018). Per Agustus 2016, bahkan tingkat perceraian di Malang Raya telah mencapai 6.175. Dari Januari hingga Mei 2016, ada 3.063 kasus perceraian yang diajukan. Sedangkan jumlah kasus perceraian yang sudah berakhir adalah 2.903 kasus. Jika melihat jumlah ini, maka, dalam sehari ada 19 janda baru di Kabupaten Malang. Sebanyak 2.032 istri menggugat cerai suaminya. Total kasus perceraian yang diputuskan sekitar 500 kasus bunuh diri dan perceraian (Jawa Pos Daily, 16 Juni 2016). Dalam sehari Gubernur Jawa Timur Khofifah Indar Parawansa harus tanda tangani 17 berkas perceraian ASN Pemerintahan Provinsi Jawa Timur (Tribune Madura.com, Rabu, 1 April 2020).

Sementara kasus perceraian di Kota Wisata Batu, Jawa Timur mengalami peningkatan 400 persen dalam rentang tahun 2014, termasuk Pegawai Negeri Sipil (PNS). Pada 2013 angka perceraian mencapai 60 kasus (Business Daily, 9 April 2015). Berdasarkan data dari Inspektorat Kota Batu, kasus perceraian PNS dalam lima tahun terakhir mencapai 61 kasus, yaitu 10 kasus pada 2010, 16 kasus pada 2011, 20 kasus pada 2012 dan sebanyak 15 kasus untuk tahun 2013. Selama 2014 ada 41 kasus (Antara News, 10 April 2015).

\section{Jumlah Kasus Perceraian Di Jawa Timur}

\section{TAHUN}

\section{JUMLAH KASUS}

\footnotetext{
${ }^{1}$ Kota selanjutnya ialah Bandung sebanyak 133.981 kasus, dan yang ketiga adalah Semarang yang mencapai 112.399 kasus (NET.Z, Rabu 12 Februari 2020).

${ }^{2}$ Penanganan kasus perceraian di Kota Wisata Batu masih dilakukan oleh Pengadilan Agama Kota Malang (PA). Anwar Saadi adalah Kepala Kantor Subdirektorat untuk Direktor Urais dan Binsyar dari Kemneterian Agama Republik Indonesia.
} 


\begin{tabular}{|l|l|}
\hline 2011 & 25.907 \\
\hline 2012 & 27.425 \\
\hline 2013 & 74.777 \\
\hline 2014 & 81.627 \\
\hline 2015 & 87.475 \\
\hline 2016 & 86.491 \\
\hline 2017 & 84.839 \\
\hline
\end{tabular}

Sumber: BPS 2016, Kementerian Agama RI, Dirjen Bimas Islam, Mahkamah Agung, Dirjen Badan Peradilan Agama Jawa Timur, OkeNews 20 Agustus 2015.

Secara keseluruhan jumlah perceraian di Indonesia telah mencapai 153.550. Tren ini mengkhawatirkan pemerintah, karena mengindikasikan rapuhnya institusi pernikahan (Harian Kompasiana, 17 Juni 2015). Di antara jumlah permohonan perceraian yang masuk tahun 2019 tercatat 604.997 kasus, 79 persen permohonan telah dikabulkan pengadilan. Berarti, lebih dari 479.618 pasangan menikah telah resmi bercerai. Mengejutkannya, selama 2019 perkara kasus perceraian yang diajukan dari pihak istri (Cerai Gugat) totalnya mencapai 355.842 kasus. Artinya penggugat cerai oleh istri sebanyak 70 persen (Liputan Enam, 20 September 2019). Sedangkan kasus perceraian yang diajukan dari pihak suami (Cerai Talak) mencapai 124.776 kasus (NET.Z, Rabu 12 Februari 2020). ${ }^{3}$ Sesuai data tersebut, terdapat dua jenis kasus perceraian yang dilaporkan pada Pengadilan Agama yaitu Cerai Gugat yang dilaporkan pihak perempuan dan Cerai Talak yang dilaporkan oleh pihak pria (Harian Detikcom, Rabu, 3 April 2019).

\section{Perkara Perkawinan Yang Diputus Pengadilan Agama Di Indonesia}

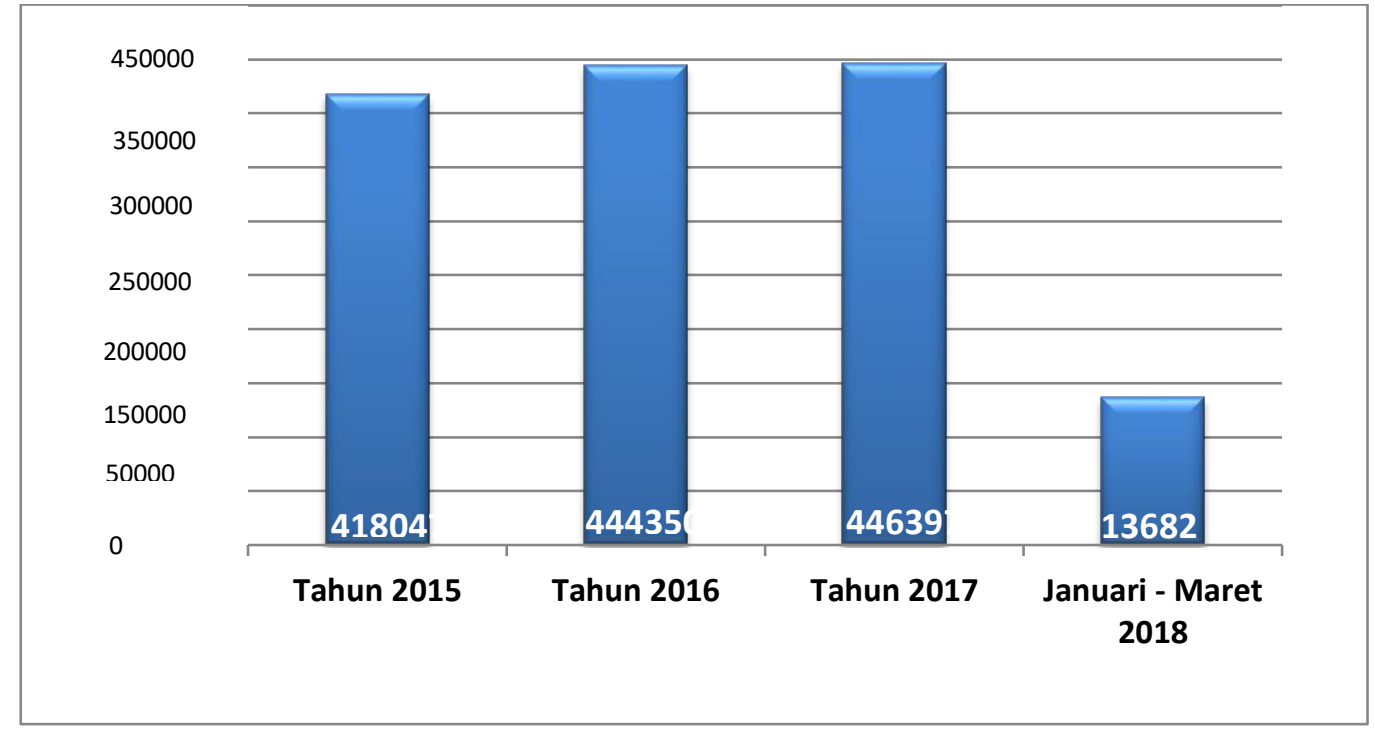

${ }^{3}$ Data Badan Pengadilan Agama (Badilag) Mahkamah Agung, 2019 dan dimuat dalam NET.Z, Rabu 12 Februari 2020 
Sumber: Sumber: BPS 2016, Kementerian Agama RI, Dirjen Bimas Islam, Mahkamah Agung,

Dirjen Badan Peradilan Agama Jawa Timur

Demikian pula, angka perceraian di Kota Wisata Batu, Jawa Timur termasuk tinggi. Tahun 2016 berada dikisaran 6000 tetapi dalam tahun 2017 hingga akhir Nopember sudah berada pada kisaran 7.000 pasangan suami istri. Artinya terjadi kenaikan sebesar 10 persen (Suara Indonesia-news.com, Jumat, 1 Desember 2017). Data Kemenag Kota Batu tercatat 300 kasus perceraian terjadi dari 1.678 perkawinan pada tahun 2018 (Jatim Times.com 17 September 2019).

\section{FAKTOR PENYEBAB PERCERAIAN DI INDONESIA}

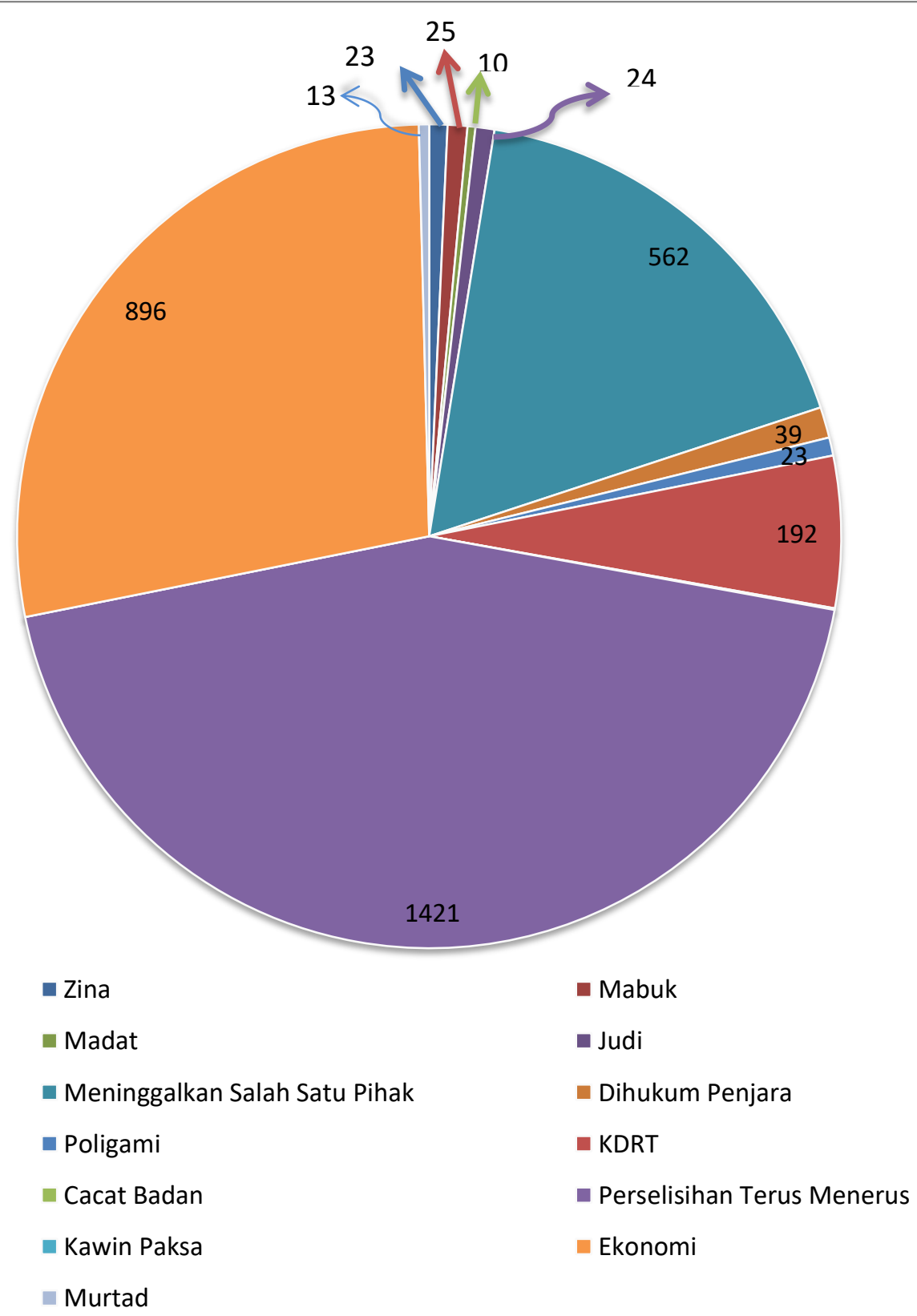

SUMBER: NET.Z, 3 Juni 2018 
Beberapa alasan selingkuh yang berakhir dengan perceraian di Indonesia meliputi: mencari variasi, pembalasan atas ketidaksetiaan pasangan, menentang norma-norma monogami, mencari kepuasan emosional yang tidak terpenuhi, suami atau istri mendorong hubungan gelap, membuktikan bahwa ia masih muda, dan hanya untuk dapatkan kesenangan (Kompas.com, 30 Juni, 2015). Ketidakmampuan suami dalam memenuhi kebutuhan ekonomi keluarga menjadi masalah yang cukup besar pada banyak kasus perceraian. Pada akhirnya, pihak istri lebih banyak yang mengambil inisiatif dan pilihan bercerai ketika dihadapkan pada masalah tersebut, tercatat 307.778. Sedangkan dari pihak laki-laki sebanyak 111.490 orang (Harian Detikcom, Rabu, 3 April 2019).

Direktur Pembinaan Tenaga Teknis Peradilan Agama Mahkamah Agung Candra Boy Seroza menegaskan penyebab tingginya angka perceraian di Indonesia adalah masalah ekonomi. Namun merurut data yang diperolehnya sebagaimana tertera di atas bahwa pertengkaran dan perselisihan dalam rumah tangga juga menjadi pemicu kedua retaknya bahtera rumah tangga. Selanjutnya diikuti oleh perzinahan, mabuk, meninggalkan salah satu pihak, dihukum penjara dan kekerasan dalam rumah tangga. Selama tahun 2019 perkara kasus perceraian yang diajukan dari pihak istri (Cerai Gugat) totalnya mencapai 355.842 kasus. Sedangkan kasus perceraian yang diajukan dari pihak suami (Cerai Talak) mencapai 124.776 kasus (NET.Z, Rabu 12 Februari 2020).

Penelitian lebih jauh mengungkapkan bahwa angka perceraian di kalangan guru di Jawa Timur, sejak tahun 2016 masih tinggi. Menurut Khofifah Indar Parawansa: "Dari 17 pengajuan cerai di Pengadilan Agama, 12 diantaranya adalah guru. Bahkan gugatan cerai kerap terjadi setelah sertifikasi. Tren peningkatan kasus perceraian 11 persen setelah guru lulus sertifikasi” (Jatim Times.com, 2016).

Secara umum faktor penyebab utama terjadinya perceraian di Surabaya pada tahun 2018 adalah: (1) Ekonomi. Menurut data BPS, perkara perceraian yang diterima oleh Pengadilan Agama pada 2018 di Surabaya berjumlah 6.153. Angka ini meningkat bila dibandingkan tahun sebelumnya mencapai 5.556. Faktor ekonomi menempati penyebab tertinggi perceraian dengan angka 1.832. Terjadi peningkatan drastis sejak 2016 (Liputan Enam, 20 September 2019). (2) Tidak Harmonis. Faktor lain yang mendominasi penyebab perceraian di Surabaya adalah hubungan yang tidak harmonis 97.615 kasus. Menurut Gubernur Jawa Timur Khofifah Indar Parawansa, penyebab perceraian di Jawa Timur adalah adanya perempuan idaman lain (Antara, Senin, 16 September 2019), yang mana kehadiran pihak ketiga 25.340 kasus, dan kecemburuan 9.338 kasus (NET.Z, Rabu 12 Februari 2020). Faktor ini menempati posisi kedua setelah ekonomi dengan angka 74.559 kasus, tidak ada tanggung jawab suami 81.226 kasus, (NET.Z, Rabu 12 Februari 2020).

Sementara di Kota Wisata Batu, ${ }^{4}$ menurut Wakil Wali Kota Punjul Santoso, penyebab utama terjadinya perceraian di Kota Wisata Batu adalah: perkawinan pada usia muda atau dibawah umur 20 tahun, faktor ekonomi yang mulai menanjak atau mapan, peselingkuhan atau hadirnya pihak ketiga dan dampak negatif dari perkembangan teknologi (Antara News, 10 April 2015).

\section{METODE PENELITIAN}

${ }^{4}$ Kota Wisata Batu dengan luas 19.909 Ha atau 199,09 Km persegi dikenal sebagai Kota Apple, karena apel adalah produk andalan mereka; Kota ini terletak di ketinggian $600 \mathrm{~m}$ di atas permukaan laut dan dikelilingi oleh Gunung Panderman, gunung Banyak, Gunung Welirang dan Gunung Bokong. 
Pendekatan terhadap topik "Bolehkah orang Kristen di Kota Wisata Batu, Indonesia Bercerai?" menggunakan Metode Deskriptif, dimana peneliti menemukan fakta dan berupaya menerapkan interpretasi yang tepat. Peneliti mempelajari masalah perceraian dalam masyarakat di Kota Wisata Batu, Jawa Timur, tatacara yang berlaku di dalamnya, sikap-sikap, pandangan-pandangan, dan proses-proses yang sedang berlangsung serta pengaruh dari fenomena perceraian masa kini bagi pasangan Kristen. Peneliti berupaya menginterpretasi, merumuskan situasi perceraian, menerangkan relasi, mendapatkan makna dan implikasi dari masalah perceraian serta respon iman Kristen berdasarkan Injil Markus 10:1-12. Oleh karenanya Peneliti menggunakan sumber-sumber primer, yakni: Alkitab, Ensiklopedia Alkitab, Tafsiran dan Exposisi Injil Markus.

\section{HASIL DAN PEMBAHASAN}

Pertanyaan apakah pasangan Kristen di Kota Wisata Batu boleh bercerai? adalah mereferensi dari pertanyaan orang-orang Farisi kepada Yesus Kristus di daerah seberang Sungai Yordan beberapa ribu tahun yang lalu oleh Markus dalam Injilnya pasal 10: 1-12, tetapi pertanyaan tersebut tetap relevan bagi orang Kristen di Kota Wisata Batu, Jawa Timur sampai sekarang. Berikut adalah hasil dan pembahasannya.

\section{Apakah Dasar Hukum Pernikahan - Perceraian Di Indonesia?}

Indonesia memberlakukan UU Perkawinan yang berdasarkan prinsip mempersulit perceraian. Landasan filosofisnya adalah bahwa perceraian akan berdampak buruk bagi pihak-pihak yang berkepentingan. Oleh karena itu ditentukan bahwa pelaksanaan perceraian harus memiliki alasan yang cukup kuat untuk suami dan istri bahwa kedua belah pihak tidak dapat hidup harmonis sebagai suami dan istri.

Secara yuridis, perceraian dinyatakan dalam UU No. 1 Pasal 38 tahun 1974 yang mengatur berbagai ketentuan bahwa "perkawinan dapat dilanggar karena kematian, perceraian, dan keputusan pengadilan." Aturan hukum positif memiliki arti sebagai berikut: 1) Hukum yang dapat dilakukan oleh suami atau istri untuk memutuskan hubungan perkawinan di antara mereka; 2) Suatu peristiwa hukum yang memutuskan hubungan suami-istri, yaitu kematian suami atau istri yang bersangkutan, yang merupakan ketentuan final dan ditetapkan oleh Allah; 3) Keputusan hukum yang dinyatakan oleh pengadilan yang berdampak hukum pada putusnya hubungan pernikahan antara suami dan istri.

Undang-Undang Nomor 1 Tahun 1974 Pasal 39 menjelaskan bahwa: (1) Perceraian hanya dapat dilakukan di depan persidangan setelah pengadilan yang bersangkutan mencoba dan gagal merekonsiliasi kedua pihak; (2) Untuk bercerai harus ada cukup alasan bahwa suami dan istri tidak akan dapat bergaul sebagai suami dan istri; (3) Prosedur perceraian di depan persidangan diatur dalam undang-undang (Syaifuddin, 2013: 16).

Undang-Undang Nomor 1 Tahun 1978 Pasal 40 menjelaskan prosedur perceraian sebagai berikut: (1) Klaim perceraian diajukan ke Pengadilan; (2) Prosedur untuk mengajukan gugatan dalam ayat Pasal ini diatur dalam undang-undang dan peraturan terpisah.

Dengan adanya legitimasi UU Perceraian, maka dapat dikatakan bahwa hal tersebut adalah sebagai salah satu bukti nyata dari niat dan kepedulian Negara Indonesia terhadap hak-hak warganya di Tanah Air umumnya dan Kota Wisata Batu, Jawa Timur khususnya. 


\section{Apakah ada Alasan Untuk Bercerai?}

Pada satu titik Yesus mengajar orang-orang di daerah seberang Sungai Yordan, yaitu: di Yudea dan Perea, seperti kebiasaannya. ${ }^{5}$ Meskipun Yesus umumnya mengajar di Sinagoge, namun ada bukti bahwa Dia juga mengajar orang banyak di udara terbuka. Di dalam Injil Markus 2:3 Yesus mengajar dan menyembuhkan orang lumpuh; 4:1 Yesus mengajar tentang perumpamaan kepada orang banyak di tepi danau; 6:6 Yesus berjalan berkeliling dari desa ke desa sambil mengajar; 6:34 Yesus mengajar lima ribu orang dan

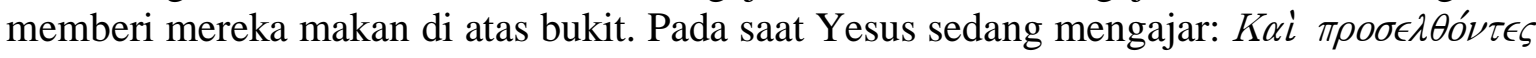

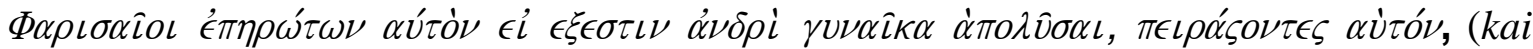
proselthontes Farisaioi epheroton auton ei exestin andri gunaika apholusai, pheirasontes auton). Dan orang-orang Farisi, yang mendekati untuk menguji Dia, bertanya kepada-Nya apakah sah bagi seorang pria untuk menceraikan istrinya?" (Edwards, 2002: p. 299).

\section{Latar Belakang Pertanyaan Tentang Perceraian}

Pertanyaan mengenai perceraian telah menjadi topik yang hangat secara politis sejak zaman Yesus di Palestina hingga saat kini. Bukan hanya Herodias yang menceraikan suaminya, ${ }^{6}$ tetapi juga Herodes Antipas menceraikan istrinya, putri Aretas yang mengetahui rencana Herodes, kemudian melarikan diri kepada ayahnya. Lane lebih suka menulis dan menafsirkan, didukung oleh teks-teks Barat dan Kaesarea, yang membahasa tentang perempuan yang "berpisah" ( $\xi^{\prime} \xi \epsilon \in \lambda \theta$ - exelthe) dari suami mereka (tanpa perceraian) dan menikahi pria lain (Lane, 1974: p. 352). Perkawinan tersebut telah menciptakan krisis politik, yang pada akhirnya menghasilkan perang antara Galilea dan Nabataea. Jika orang Romawi tidak mengintervensinya, maka kemungkinan Herodes Antipas kehilangan kerajaannya. Dalam situasi berbahaya seperti ini, maka dapat dipahami mengapa Tetrach dari Galilea tidak bisa mentolerir kritik tajam atau lebih tepatnya kecaman Yohanes Pembaptis terhadap Antipas dan popularitasnya di tengah-tengah masyarakat. Pada akhirnya kritik Yohanes Pembaptis tentang perceraian dan pernikahan kembali Herodes Antipas membahayakan hidupnya, yang kemudian mati dengan cara yang tidak lazim (Evans, 2001: 83).

Ada beberapa keraguan tekstual tentang identitas orang yang menguji Yesus yang

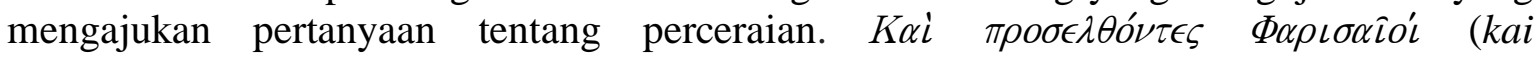
proselthontes Farisaioi) untuk mengujinya - (partisipnya adalah purposive). Markus memberi penjelasan bahwa motif pertanyaan orang Farisi bukanlah pertanyaan sederhana; ini lebih merupakan "ujian," lebih tepatnya sebagai perangkap atau jebakan untuk menjebak Yesus (Mrk. 8: 11; 10: 2; 12: 15). Jika Yesus berada di Perea, yang berada di bawah yurisdiksi Antipas, maka pertanyaan tersebut mungkin sebagai jebakan terhadapnya oleh karena pernikahan Antipas dengan Herodias, di mana Yohanes Pembaptis telah kehilangan kepalanya (Mrk. 6: 18). Jika konteks pertanyaannya adalah demikian, maka pertanyaan yang diajukan para Farisi kepada Yesus adalah: Apakah Antipas dibenarkan atau tidak menceraikan putri Raja Aretas untuk menikahi Herodias? Sebaliknya, jika pertanyaan tersebut tidak memiliki motif politik, maka orang-orang Farisi tentu mencurigai Yesus bahwa Dia memiliki perspektif tentang perkawinan yang berbeda dari mereka.

5 Meskipun Yesus umumnya mengajar di Sinagoge, tetapi terdapat bukti bahwa Yesus juga mengajar orang banyak di alam terbuka. Dalam Injil Markus 2:13 di pantai danau; 4: 1 di tepi danau; 6: 6 berjalan berkeliling dari desa ke desa sambil mengajar; 6: 34 di atas bukit. (Meskipun Yesus Umum mengajar di sinagoge, ada bukti bahwa Yesus mengajar orang banyak di udara terbuka. Dalam Injil Markus 2: 13 di pantai danau; 4: 1 di tepi danau; 6: 6 berjalan dari desa ke desa sambil mengajar; 6: 34 di atas bukit).

${ }^{6}$ Lane lebih suka membaca, didukung oleh teks-teks Barat dan Kaisarea, yang berbicara tentang wanita yang "berpisah" ( $\epsilon \nu \xi^{\prime} \in \lambda \theta \eta$ - exelthe) dari suaminya (tanpa perceraian) dan menikahi pria lain. 
Tujuan utama para Farisi adalah menghancurkan posisi Yesus dengan menyebabkan-Nya berkompromi dengan otoritas Taurat.

Pertanyaan yang diajukan oleh orang-orang Farisi kepada Yesus yang merupakan teman pelayanan Yohanes Pembaptis, memiliki potensi bahaya yang sama. Terdapat beberapa bukti bahwa Yesus mengutuk tindakan Herodes, merujuk pada Herodes Antipas yang ingin membunuhnya dan yang takut bahwa Yesus mungkin benar-benar dibangkitkan oleh Yohanes Pembaptis dari kematian (Lih. Luk. 13: 31-32; Mrk. 6: 16). Yesus merujuk pada "buluh yang diombang-ambingkan oleh angin" dan "seorang pria yang mengenakan pakaian lembut" (Lih. Mat. 11: 7-8; Luk. 7: 24-25), berbeda dengan Yohanes Pembaptis (Mat. 11: 9; Luk. 7: 26). Mungkin juga bahwa "bangsawan tertentu" dalam perumpamaan tentang "Uang Mina" (Luk. 19: 11-27) pada awalnya merupakan kritik terselubung yang ditujukan kepada Herodes Antipas atau kepada saudaranya Herodes Arkhelaus. Dalam perumpamaan tersebut sosoknya diilustrasikan sebagai Pencuri dan Pembunuh (Evans, 2002: p. 83).

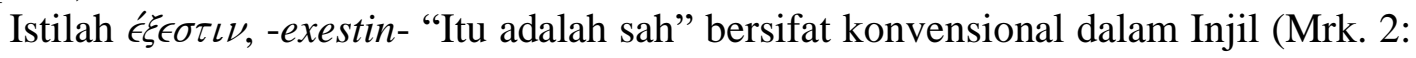
24, 26; 3: 4; 6: 18; 12: 14 dan paralel Yoh. 5: 10; 18: 31), tetapi relatif jarang digunakan dalam LXX. Contoh terakhir adalah signifikan, meskipun bentuk partisipatif dengan ketidaksempurnaan $\epsilon \hat{L} \nu \alpha \iota$, ,Being," digunakan: "Itu tidak syah untuk Ananus [ou่ké $\xi o \nu \eta \nu$

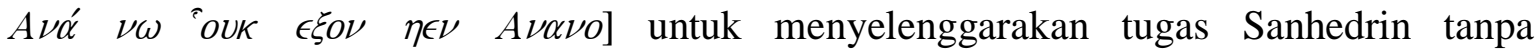

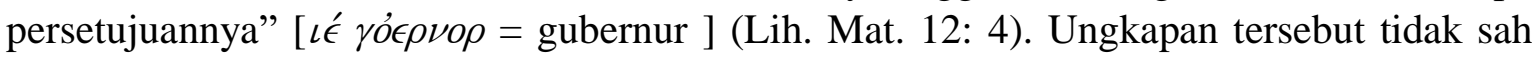
bagi seorang perempuan, tanpa Advokat, untuk berbicara di hadapan seorang hakim (Evans, 2001: p. 84). Dengan demikian, pertanyaan orang-orang Farisi tersebut dilatarbelakangi oleh intrik-intrik percintaan, politisasi agama dan tahta kekuasaan. Lalu, apakah esensi pertanyaan para Farisi mengenai legalitas perceraian?

\section{Esensi Pertanyaan tentang Perceraian}

Catatan Markus mengenai pertanyaan orang-orang Farisi mengejutkan karena, sebagaimana telah diketahui, hukum Yahudi mengizinkan perceraian. Satu-satunya pertanyaan yang berkaitan dengan dasar perceraian, seperti yang dicatat paralel dalam Matius 19: 3 adalah: "Apakah sah bagi seorang pria untuk menceraikan istrinya untuk setiap alasan?" Ungkapan terakhir ini adalah inti dari suatu perceraian yang kontroversi seperti yang tercermin dalam Mishnah:

The School of Shammai says: A man cannot divorce his wife unless he has found impurity in him, because it is written, "Because he has found indecency in all things." And the School of Hillel said: [He can divorce her]. Even if he spoil the dish for him, because it is written, "Because he has found indecency in anything." R. Akiba said: Even if he finds the others more just than he, because it is written, "And that would be if he did not find good in his eyes." (Edwards, 2002: p. 299).

Orang Yahudi dan para ahli agama Yahudi setuju bahwa pasangan suami dan istri boleh melakukan perceraian. Sekolah yang lebih konservatif yakni Shammai, berpendapat bahwa satu-satunya dasar perceraian adalah "indencensi," yaitu perzinahan, sedangkan sekolah liberal Hillel berpendapat bahwa perceraian dapat diperbolehkan "untuk kasus apa pun" (NIV, "untuk setiap dan semua alasan"; Mat. 19: 3), yaitu, karena ada banyak faktor penyebab selain kasus perzinahan.

Bahkan di antara kaum Eseni di Qumran, faksi konservatif Yudaisme pada zaman Yesus melarang perceraian secara keras. Tetapi mengingat penerimaan universal perceraian di antara orang-orang Yahudi abad pertama, maka tampaknya cukup rasional untuk menyimpulkan bahwa perceraian dapat terjadi "untuk masalah apa pun." Hal 
tersebut tersirat melalui pertanyaan orang-orang Farisi kepada Yesus (ayat 2). Orang Yahudi abad pertama menambahkan frasa "untuk masalah apa pun" ke dalam pertanyaan, yang telah dihilangkan untuk kenyamanan, tetapi terlepas dari hal ini, pertanyaan tersebut tidak masuk akal. Pertanyaan yang ditujukan kepada Yesus sepertinya pertanyaan singkat yang konotasinya sepenuhnya melampaui kata-kata di telinga pendengar. "Apakah sah bagi seorang pria untuk menceraikan istrinya dengan alasan masalah tanah selain perzinahan?" (Edwards, 2002: pp. 300).

Orang-orang Farisi mendeskripsikan pandangan mereka bahwa pernikahan adalah pengaturan kontrak satu kali. Dua kali mereka bertanya kepada Yesus tentang kemungkinan pembubaran pernikahan (10: 2, 4). Titik awal dalam diskusi orang-orang Yahudi tentang perceraian adalah mengacu pada Ulangan 24: 1-4 yang mengandung multitafsir.

Sertifikat perceraian menjadi garansi perceraian dan hak untuk menikah lagi dengan pria lain jika ia memilihnya. Dengan demikian melindungi hak-hak perempuan semaksimal mungkin dalam budaya patriarkal, meskipun perceraian memang menyebabkan stigma karena seorang imam dilarang menikahi seorang janda (Im 21: 7) dan pernikahan kedua "mencemarkan" (U1 24: 4) istri pertama. Implikasinya istri pertama atau mantan istri tersebut tidak bisa lagi menikah dengan suami pertamanya. Oleh karenanya Yesus Kristus tidak pernah mengijinkan perceraian!

Dengan demikian, sebagaimana yang dimaksud pada awalnya (Ul 24: 1-4) tidak mendorong perceraian, tetapi lebih berusaha untuk mempertahankan peraturan yang setara dalam hal peristiwa perceraian yang tidak menguntungkan. Namun pertanyaan orang-orang Farisi dalam ayat 4, merujuk pada Ulangan 24: 1-4 tidak lagi berfungsi membatasi efek buruk perceraian, tetapi lebih sebagai dalil perceraian, "Jika seorang pria menemukan sesuatu yang tidak senonoh pada istrinya."

Seperti yang telah dipaparkan sebelumnya bahwa teks-teks sebelumnya berkisar pada perzinahan saja, sampai alasan yang paling lemah, termasuk kegagalan seorang istri dalam menjalankan tugas-tugas rumah tangga yang sederhana atau kegagalan dalam hal menyenangkan suaminya seperti yang dilakukan oleh perempuan lain (Edwards, 2002: p. 301). Tujuannya adalah untuk mempertahankan kebijakan perceraian yang permisif - dan semakin permisif semakin baik.

Pada hakekatnya, pertanyaan orang-orang Farisi kepada Yesus adalah untuk menguji-Nya, mencari pembenaran dan dukungan sebagai refleksi dari motivasi terselebung untuk menjatuhkan Yesus melalui pertanyaan yang problematis dan dilematis untuk menjaga zona nyaman perceraian. Schurer merangkum posisi orang-orang Yahudi mengenai perceraian sebagai berikut: "Perceraian relatif mudah dilaksanakan pada waktu itu dan orang-orang Farisi serta para Rabi ingin tetap demikian." Jangan diamandemen oleh Yesus. (Schurer, A History of the Jewish People In The Time of Jesus Christ: 2.468)

\section{Bagaimana Respon Yesus Terhadap Perceraian (Mrk. 10: 1-12)?}

Mengamati dan menanggapi kasus perceraian yang meningkat tajam dan masiv pada saat ini di Indonesia pada umumnya dan di Kota Wisata Batu, Jawa Timur khususnya, maka peneliti menganalisis, merumuskan dan mengacu pada tanggapan Yesus terhadap kasus perceraian suami - istri yang mengacu pada Markus 10: 1-12 yang meliputi: mandat pernikahan, komitmen pernikahan, dan larangan perceraian. Hasil analisis teks dogma tersebut peneliti menjadikannya sebagai presaposisi, perspektif dan acuan menghadapi kasus perceraian di Kota Wisata Batu saat ini. 


\title{
Mandat Perkawinan
}

Amanat atau mandat pernikahan ialah bahwa Allah merancang dan menciptakan pria dan perempuan karena teks Markus 10: 6 menegaskan: "Karena pada awal dunia, Allah menjadikan mereka laki-laki dan perempuan" dan diakhiri dengan "sehingga keduanya itu menjadi "satu daging" (Mrk 10: 8) mengutip kata demi kata dari Kejadian 1: 27; 2:24. Keadaan pada awal dunia merupakan petunjuk tentang cita-cita Allah. Maksud Allah terhadap pernikahan adalah sebagai suatu persatuan seumur hidup dalam segala hal.

Pernikahan Kristen adalah desain ilahi, sebagai perjanjian ilahi antara: Allah, satu suami dan satu istri. Pernikahan bukan ide manusia tetapi adalah lembaga ilahi, sehingga tidak dapat dibatalkan atau bahkan diubah oleh otoritas apa pun yang lebih rendah dari yang pertama diciptakan (Alexander, 1986: p. 275). Karena itu harus ada perbedaan antara kehendak mutlak Allah dan ketentuan-ketentuan yang memperhitungkan dosa manusia dan dimaksudkan untuk membatasi dan mengendalikan dampaknya. RUU perceraian Musa (di Mahkamah Agama) termasuk dalam kategori kedua (Gabelein, 1984: p. 711).

Mandat ilahi untuk menikah tidak dapat ditentukan dari teks tentang perceraian (Edwards, 2002: pp. 301-302). Tuhan Yesus memiliki perspektif dan tindakan berbeda tentang pernikahan. Dia tidak terjebak dalam tatanan hukum formal karena pernikahan bukan merupakan akta atau tindakan transaksional. Yesus berusaha memulihkan kehendak Allah Bapa untuk menikah, bukan berdebat tentang dispensasi. Lawannya bertanya apa yang diizinkan; Yesus menunjuk pada apa yang diperintahkan (Hooker, 2009: 235). Ulangan 24: 1-4, menurut Yesus bukanlah dalih, alasan atau dasar untuk perceraian tetapi upaya untuk membatasi konsekuensi terburuk bagi perempuan.

Yesus membenarkan oposisi yang tidak memiliki kualifikasi untuk perceraian dan memberikan interpretasi dengan mereferensi: $\alpha \pi \dot{o} \delta \dot{\epsilon} \dot{\alpha} \rho \chi \hat{\eta} \varsigma \kappa \tau \dot{\iota} \sigma \epsilon \omega \varsigma$ "Tetapi sejak awal penciptaan." Yesus merujuk pada hukum yang tersirat yang didasarkan pada ciptaan itu sendiri (Mrk 13: 19), sesungguhnya, penciptaan manusia (laki-laki) dan perempuan. Yesus merujuk kembali kepada ciptaan yang asli (ayat 6), ketika Allah menciptakannya laki-laki dan perempuan. Murray menjelaskan sebagai berikut:

\begin{abstract}
Marriage is grounded in this male and female constitution: as to its nature it implies that man and the woman are united in on flesh, as to its sanction, it is divine; as to its continuance it is permanent. The import of all this is that marriage from its very nature and from the divine institution by which it is constituted is ideally indissoluble. It is not a contract of temporary convenience and not a union that may be dissolved at will (Murray, 1974: $\mathrm{p}$. 29).
\end{abstract}

Mandat penciptaan laki-laki dan perempuan adalah bertujuan untuk menyatukan

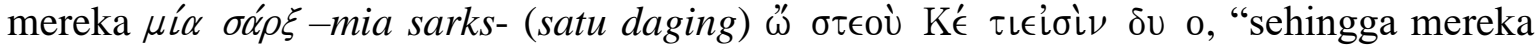
tidak lagi dua" adalah ekspresi Semitik yang berarti "satu", maka tidak mungkin Tuhan menghendaki mereka bercerai. Pernikahan melibatkan kesatuan seksual antara pria dan perempuan (Kej. 1: 24; Mat 19: 5; Ef 5: 31). Tiga tujuan hubungan seksual dalam pernikahan, yaitu: (1) Penyatuan (Kej. 2: 24); (2) Reproduksi (Kej. 1: 28); (3) Rekreasi (Ams. 5: 18-19). Perceraian sama saja dengan pembatalan mandat Allah. Aturan Musa, yang diberikan kepada orang-orang yang keras kepala dan keras hati, harus ditafsirkan dalam terang ini.

Bahwa pernikahan adalah penyatuan laki-laki dan perempuan lebih jauh dibuktikan oleh referensi untuk "ayah dan ibu" dan kepada laki-laki yang "dipersatukan dengan istrinya" dalam ayat 7. Bahwa "mereka bukan lagi dua, tetapi satu" (ayat. 8) dan "Apa yang telah dipersatukan Allah, tidak boleh diceraikan oleh manusia" (ayat 9). Dua kali orang-orang Farisi bertanya tentang dispensasi pernikahan dan dua kali Yesus menyatakan 
Kehendak Tuhan yang mula-mula diungkapkan dengan cara Allah pada awalnya menciptakan manusia sebagai laki-laki dan perempuan, dua orang dimaksudkan untuk menjadi "satu daging."

Bagi para Farisi, tidak ada perbedaan antara "Tuhan" dan "Musa." Seperti dalam 7: 9-10, perintah Musa diidentifikasikan dengan Allah. Para lawan Yesus mengutip dari Kitab Suci yang menyatakan bahwa kehendak Allah yang asli ditetapkan dalam ciptaan, di mana hukum Musa kelak hanyalah merupakan sebuah proposisi atau dalil, konsesi dan dalih atau alasan untuk mengeraskan hati (Kej. 1:27; 2:24).

Untuk membedakan mandat ilahi bagi pernikahan, maka Yesus merujuk pada otoritas Taurat, mengacu pada otoritas sebelumnya dan lebih mendasar dalam susunan ciptaan: pada awal penciptaan Allah "menjadikan mereka laki-laki dan perempuan." Dalam pernyataan tersebut Yesus sekali lagi mengandaikan otoritas ilahi berdiam atau tinggal dalam diri-Nya sendiri, karena Yesus tidak menyimpulkan dari Kitab Suci (seperti para ahli Taurat), tetapi Yesus menyatakan kehendak Allah sebagaimana ditentukan dalam teks penciptaan yang menentang teks hukum Musa (Manson, 1951: pp. 291-293).

Bagi Markus, otoritas Yesus, bukan terletak pada kekuatan argumen atau otoritas Alkitab, tetapi merupakan inti dari keseluruhan diskusi. Ungkapan alkitabiah ini tidak hanya merujuk pada kesatuan seksual antara suami dan istri, tetapi juga berarti bahwa pasangan tersebut adalah seorang yang sebenarnya, bukan dua orang yang memiliki cara mereka sendiri yang sementara disatukan oleh suatu pengaturan kontrak. Mereka bukan lagi dua tetapi satu (Boring, 2006: p. 287).

Jadi, pernikahan adalah amanat atau mandat Tuhan sebelum Adam dan Hawa jatuh ke dalam dosa. Pernikahan Kristen bersifat monogami yaitu merupakan satu kesatuan antara satu laki-laki (suami) dengan satu perempuan (istri), dan tidak merekomendasi pernikahan antara laki-laki dengan laki-laki atau perempuan dengan perempuan.

\section{Komitmen Pernikahan}

Komitmen pernikahan bersifat permanen: “... karena telah dipersatukan oleh Tuhan." $\sigma \cup \nu \epsilon \zeta \in \cup \xi \in \nu$ - synezeuxen- secara harfiah berarti "sungguh-sungguh atau benarbenar (aorist) dipasangkan bersama" (NIV, gabung bersama). Kata tersebut sering digunakan dalam literatur Yunani tentang hubungan pernikahan (Gaebelein, 1984: p. 712). Pengertian lebih luas dari kata synezeuxen adalah "bersama-sama disatu-kuk-kan, atau bersama-sama dalam kuk yang sama yang telah diciptakan untuk mereka." Yesus menggambarkan pernikahan sebagai sebuah kuk yang dibuat oleh Allah. Seorang suami dengan seorang istri dapat memikulnya atau menanggungnya sehingga mereka bersamasama dapat meringankan beban hidup. Mencapai hal-hal bersama yang tidak dapat dicapai jika mereka hanya seorang diri atau sendirian.

Istilah пробко $\lambda \lambda \theta \in \sigma \in \tau \alpha \iota$-proskolléthésetai- (pasif, indikatif) artinya terus-menerus disatukan, dan dikokohkan bersama, ditata bersama. Proskolléthésetai mengindikasikan tingkat kekuatan paling tinggi dalam suatu kondisi kedekatan dan keterikatan. Ruang dan waktu bukanlah masalah utama. Artinya jelas, bahwa dalam pernikahan; seorang lelaki melekatkan dirinya pada istrinya sendiri, sehingga "apa yang telah dipersatukan Allah tidak boleh diceraikan oleh manusia."

Di balik konsep komitmen tidak tercerainya suatu perkawinan adalah otoritas Tuhan sendiri. "Perceraian bertentangan dengan institusi ilahi, komitmen pernikahan, dan tindakan ilahi. Justru di sini kejahatan menjadi sangat jelas. Perceraian adalah pemutusan segel yang telah diukir oleh tangan Tuhan." (Murray, 1974: p. 33; Gaebelein, 1984: p. 712).

Ajaran Yesus tentang pernikahan diatur oleh pemahaman baru tentang peran dan tanggung jawab suami dan istri dalam pernikahan. Dalam Hukum Yahudi, kekuatan atas 
pernikahan dan perceraian terletak di tangan laki-laki - sebagai ayah, suami, atau anak lakilaki. Sebuah diskusi tentang Bilangan 30, menunjukkan sejauh mana komitmen pernikahan laki-laki diperlukan untuk meratifikasi atau membatalkan janji pernikahan seorang perempuan.

Jadi, Yesus mengajarkan komitmen pernikahan berdasarkan pada pemahaman yang berbeda tentang perempuan. Mengutip Kejadian 1: 27 (10:6), Yesus mengakui bahwa Allah menciptakan manusia secara unik sebagai laki-laki dan perempuan. Alkitab secara jelas dan tegas menyebutkan dua jenis kelamin, Yesus menyatakan bahwa kelelakian dan keperempuanan berakar dalam kehendak kreatif Allah dan merupakan dasar pernikahan. Sebagai ciptaan yang berdaulat, perempuan bukanlah subyek laki-laki melainkan setara. Menarik lebih jauh ke teks penciptaan tambahan dari Kitab Kejadian 2:24 dalam 10: 7-8, Yesus menyatakan bahwa kewajiban seorang suami untuk istrinya melampaui kewajibannya kepada orang tuanya sendiri. Dalam Taurat perintah untuk menghormati orang tua adalah salah satu dari Sepuluh Perintah Tuhan dan merupakan perintah yang kedua setelah perintah untuk menghormati Allah (Kel. 20: 12). Tetapi efek dari ayat 7 adalah untuk menyatakan bahwa kesetiaan seorang suami kepada istrinya dalam ikatan pernikahan melampaui kesetiaannya kepada ayah dan ibu, menjadikan pernikahan kedua setelah ketaatan kepada Allah dalam kesucian dan kesakralan. Persatuan laki-laki dan perempuan dalam perikahan menghasilkan "satu daging," ciptaan baru itu sendiri, "tidak lagi dua, tetapi satu," persatuan seumur hidup.

\section{Larangan Bercerai}

Ketika Yesus sementara berada di seberang sungai Yordan, orang-orang Farisi datang untuk mencobai Dia melalui satu pertanyaan jebakan namun teologis (Mrk. 10: 2): "Apakah seorang suami diperbolehkan menceraikan istrinya?" Namun sesungguhnya mereka telah memiliki jawaban dengan merujuk pada Ulangan 24: 1-4. Yesus menanggapi

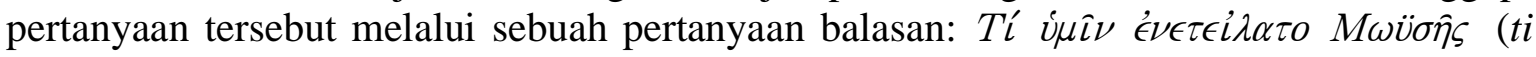
humineneteilato Mouses?) “Apa yang diperintahkan Musa kepadamu?" (Mrk. 10: 3).

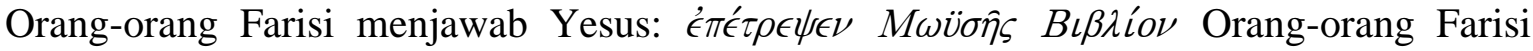

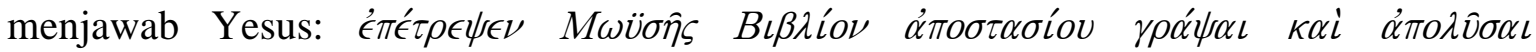
(ephetreyen Mouses Biblion aphostasiou grayaikai apholusai) "Musa memberikan izin untuk menceraikannya dengan membuat surat cerai" (Mrk. 10: 4). Perhatikan bahwa orang-orang Farisi terebut tidak menyebutkan kualifikasi izin untuk perceraian menurut Musa. Meskipun Musa memiliki otoritas dalam teks tersebut, namun Yesus tidak menerimanya sebagai konklusif untuk masalah perkawinan dan perceraian. Bahwa alasan Musa memberikan teks tersebut adalah karena: "kekerasan hatimu." Dengan kata lain, ini adalah teks Konsesi Perceraian, dan bukan teks Konstitusi Perceraian. Perhatikan Konsesi

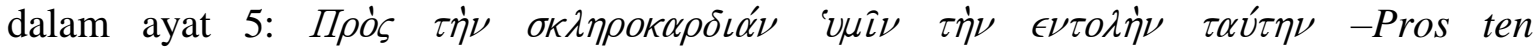
sklerokardian humin ten entolen tauten-. "Karena kerasnya hatimu dia menulis perintah ini untukmu." Yesus mengesampingkan pilihan-pilihan terebut dan sebaliknya menantang asumsi hermeneutis orang-orang Farisi bahwa karena sesuatu, maka "diizinkan" tetapi bukan kehendak Allah. Memang, menurut Maleakhi 2:16, Tuhan "membenci" perceraian. Bahkan para rabi mengakui bahwa Surga meneteskan air mata setiap kali pernikahan berakhir dengan perceraian. Yesus berpendapat bahwa Musa mengijinkan perceraian "dapat dianggap sebagai akibat dari kekerasan hatimu."

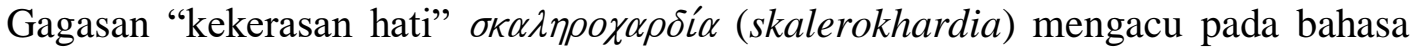
alkitabiah dari Ulangan 10:16 dan para nabi (Yer. 4: 4; Yeh. 3: 7). Dengan sendirinya kata tersebut akan dianggap sebagai teguran yang menyakitkan, sekali lagi melemparkan Yesus dalam peran seorang nabi. Tetapi bagi para pengamat Torah, perintah-perintah Musa 
adalah otoritas tertinggi atas setiap pertanyaan. Dalam Taurat lazimnya yang memerintah

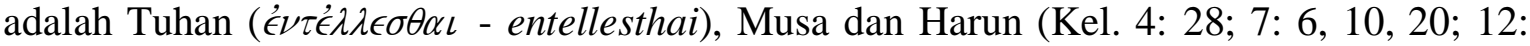
28), tetapi perhatikan perbedaan dalam Ulangan 31:23, di mana dalam bahasa Ibrani sejatinya Tuhan yang memerintahkan Yosua, tetapi dalam LXX adalah Musa yang memerintah (Evans, 2001: p. 83).

Atas dasar apakah perceraian diizinkan terjadi? Atau, jika orang-orang Farisi mencurigai bahwa Yesus, seperti orang Esseni dan mungkin seperti Yohanes, tidak akan mengizinkan perceraian sama sekali, kemudian atas dasar apa Yesus mengabaikan perintah Musa? (Gundry, 1992: p. 532).

Para rabi membahas arti "ketidaksenonohan dengannya" (Ul. 24: 1) dan "tidak menyukainya." Bahasanya ambigu. Perzinaan pada mulanya tidak terlihat, oleh karena hal tersebut dilakukan di tempat lain, dan pada zaman kuno tindakan tersebut dianggap sebagai pelanggaran berat (Im. 20:10; "Jika seorang pria menikahi istri tetangganya, maka keduanya akan dihukum mati" (Ul. 22: 13-27). Sekolah Shammai menafsirkan "erwat dabar" secara konservatif, sebagai kenajisan, sementara Sekolah Hillel menafsirkannya jauh lebih fleksibel. Bahwa seorang suami dapat menceraikan istrinya, bahkan jika dia baru saja merusak makan malamnya. Rabi Aqiba mengatakan, bahkan jika suami menemukan perempuan lain lebih cantik daripada istrinya, seperti yang dikatakan, 'Jika dia tidak menemukan kebaikan di matanya' (Gundry, 1992: p. 532).

Yesus tidak mempermasalahkan hukum Taurat, tetapi menjawab prinsip pertama. Bahwa izin Musa untuk bercerai (ayat 4) adalah akomodasi bagi kelemahan manusia (ayat 5). Hal tersebut adalah sebagai upaya untuk menciptakan ketertiban dalam masyarakat yang mengabaikan standar-standar Tuhan. Namun bukan hal tersebut yang dimaksud oleh Tuhan dalam pernikahan. Tuhan mengizinkan perceraian, namun itu bukan karena kehendak-Nya yang sempurna tetapi karena keberdosaan manusia. Tujuan hukum Musa adalah untuk memeriksa perceraian (dan melindungi perempuan yang relatif tidak berdaya), bukan bertujuan mendorong mereka untuk bercerai. Otoritas agama tidak pernah mempertimbangkan opsi ini. Suami atau laki-laki, di dalam posisi ini hidup dalam perzinahan dengan istrinya, dan bukan karena perceraian tetapi karena menikah lagi. Bahkan sekalipun dia telah melakukan semua prosedur perceraian, namun di hadapan Allah dia masih terikat dengan istri yang pertama. Pengecualian perzinahan ditambahkan oleh Matius dalam Injilnya (19:9).

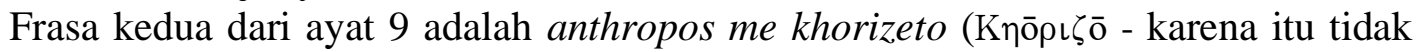
boleh diceraikan oleh manusia atau bercerai) - artinya "membagi, memisahkan, atau menghancurkan, membagi dengan orang lain." Perceraian formal biasanya didahukui oleh terpisahnya hubungan antara suami dengan istri, atau akibat tindakan suami atau istri, maupun pihak ketiga. Apa yang telah dipersatukan Tuhan tidak memberikan rekomendasi kepada manusia untuk menceraikannya (Gundry, 1992: p. 531). Perbedaan antara Allah, yang menciptakan, dan manusia, yang diciptakan, harus dipertimbangkan (Evans, 2001: p. 84). Siapakah manusia sehingga bisa memisahkan apa yang telah dipersatukan oleh Allah sendiri? Perceraian, untuk alasan apa pun dan dengan tujuan apa pun yang dapat dibenarkan secara ilmiah, dengan pertimbangan logis sekali pun, tetap melanggar rancangan Allah untuk pernikahan manusia. Tuhan tidak pernah menghendaki perceraian!

Pada dasarnya izin untuk bercerai tidak berarti menyetujui adanya perceraian. Aturan yang ditetapkan oleh Musa sejatinya bukan perintah (konstitusi-imperatif), tetapi pilihan (konsesi-subjunktif) yang disebabkan oleh kondisi spiritual manusia yang sangat tidak memuaskan. Jikalau demikian, apakah sebabnya Musa memerintahkan untuk memberikan Surat Cerai jika seseorang menceraikan istrinya? (Mrk. 10: 1-12; Mat. 19: 7, lih. Ul. 24: 1-5). Yesus menjawab pertanyaan ini secara tegas, jelas dan tuntas: "karena ketegaran hatimulah, maka Musa mengizinkanmu untuk menceraikan istrimu," tetapi sejak 
semula tidak demikian. Jadi, menurut pikiran mereka adalah bahwa perintah itu dinyatakan oleh Yesus sebagai izin (konsensus), dan bahkan itu pun secara terpaksa. Karena kekerasan hati manusia dan bukan karena kehendak absolut (konstitusi) Allah yng mutlak. Perceraian adalah dosa dan itu berada di bawah penghakiman Allah.

Jika perceraian benar-benar bukan kehendak Tuhan tetapi sebenarnya terjadi dalam ketegangan historis dengan Pencipta itu sendiri, lalu apa hasilnya? Tentunya hal tersebut menghasilkan perzinahan: $\lambda \dot{\epsilon} \gamma \epsilon \hat{i}$-le gei- (katanya) menekankan pernyataan Yesus yang

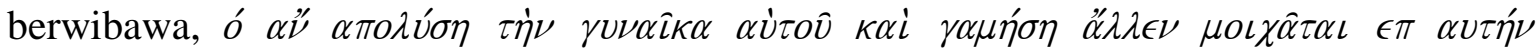
(Siapa pun yang menceraikan istrinya dan menikahi perempuan lain melakukan perzinahan

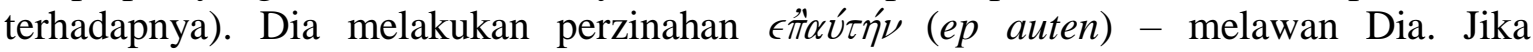
diterjemahkan "melawannya," artinya menentang istri yang sudah diceraikan, kemudian pindah ke perempuan lain, yang sebenarnya laki-laki tersebut masih terikat pernikahan dengan istri pertamanya tersebut. Dia telah melanggar salah satu dari Sepuluh Perintah: "Kamu tidak boleh melakukan perzinahan" (Kel. 20:14 = Ul. 5:18). Namun, dalam terang teks ini, bagaimana pun, perceraian hanya bisa menjadi upaya atau pilihan terakhir, dan tidak pernah bisa "tidak bersalah" (Boring, 2006: p. 288). Meskipun Yesus tidak merujuk pada "tradisi manusia" di sini seperti yang Ia lakukan dalam 7:8, namun argumennya sama (Evans, 2001: p. 85). Tatacara Allah, yang jelas sejak penciptaan, mengidentifikasi perceraian sebagai alat dosa, bukan cara untuk menghindarinya.

Perceraian menuntun seseorang kepada perzinahan melalui pernikahan lagi; hal tersebut tidak bebas dari perzinahan dalam pernikahan lain. Posisi yang diposisikan di

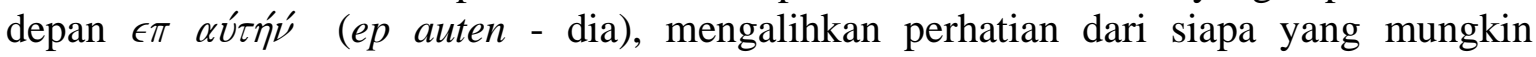
mecampakkan istrinya kemudian beralih kepada perempuan lain yang mungkin sudah menikah. Yesus menegaskan dan mengidentifikasi tindakan tersebut sebagai perzinahan. Seorang pria melakukan perzinahan dengan istrinya dengan menceraikannya dan menikahi perempuan lain, dan sebaliknya seorang perempuan melakukan perzinahan terhadap suaminya dengan menceraikannya dan menikahi pria lain (Rm. 7: 2-3). (Taylor, 1966: pp. 420-421). ${ }^{7}$

Dalam ayat 11 adalah masukan independen yang disisipkan oleh Markus, seperti versi yang dimodifikasi dan dimoderasi (Mat 5: 31-32; 19: 9; 1 Kor 7: 10-13), pepatah ini melambangkan larangan mutlak Yesus terhadap perceraian. Seperti para nabi Perjanjian Lama, Yesus tidak mengendalikan perintahnya dengan kondisi-kondisi situasional, tetapi mengumumkan kehendak mutlak Allah.

Meskipun Taurat Musa mengizinkan perceraian, oleh karena dilatarbelakangi oleh orang-orang Farisi yang menguji Yesus, yang pastinya mereka mengetahui, namun tentu saja Yesus paham bahwa Taurat melarang perzinahan; dengan mendefinisikan perceraian sebagai memfasilitasi perzinahan, Yesus mendefinisi, mendeskripsikan dan mengidentifikasi perceraian sebagai pelanggaran terhadap kehendak Allah yang dinyatakan dalam Taurat. Deklarasi Yesus adalah radikal dalam menegaskan bahwa manusia dapat melakukan perzinahan dengan istrinya ${ }^{8}$ - dalam Perjanjian Lama dan pemahaman Yahudi kuno, hanya hak-hak suami, bukan istri, bisa dilanggar oleh perzinahan.

Dalam beberapa situasi, perceraian dapat menjadi kesempatan untuk pertobatan, pengakuan bahwa seseorang telah gagal untuk hidup menurut kehendak Allah, dan oleh kasih karunia Tuhan, seperti tetap dalam status pernikahannya dalam situasi yang tidak

\footnotetext{
${ }^{7}$ Argumennya adalah bahwa tradisi teks tidak hanya mendukung bacaan ini kuat tetapi juga sangat sesuai untuk situasi Herodias dan Herodes Antipas.

${ }^{8}$ Dalam Perjanjian Lama dan pemahaman Yahudi Kuno, hanya hak seorang suami, bukan seorang istri, yang dapat dilanggar dengan perzinahan.
} 
mungkin mengeksresikan etika "hidup sesuai standard Alkitab," sambil menjauhkan seseorang dari kegagalannya sendiri oleh kasih karuania Tuhan.

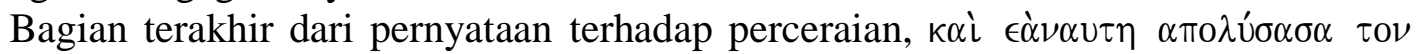

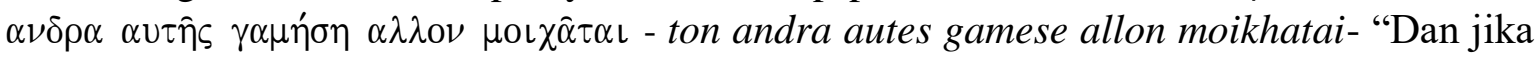
dia, menceraikan suaminya (ay. 12), menikah dengan laki-laki lain, maka dia melakukan perzinahan." Tampaknya berdasarkan Hukum Yahudi, maka seorang perempuan Yahudi tidak bisa menceraikan suaminya. Ungkapan "dan jika dia menceraikan suaminya" mengindikasikan bahwa Yesus Kristus mengakui hak perempuan untuk menceraikan suaminya, hak yang tidak diakui dalam Yudaisme (Gaebelein, 1984: p. 712). ${ }^{9}$

Catatan Markus menjelaskan bahwa tidak ada tanggapan dari orang-orang Farisi terhadap pengajaran Yesus tentang perceraian (Evans, 2001: p. 85-86). Sebaliknya, Markus langsung beralih kepada ajaran Yesus kepada Dua Belas murid-Nya. Murid-murid segera menjawab: perceraian dan pernikahan kembali oleh suami atau istri adalah perzinahan karena perzinahan terhadap suaminya; dan bagi seorang suami yang melakukan hubungan seksual dengan perempuan lain adalah sama nilainya dengan melakukan perzinahan terhadap istrinya. Yesus, dengan menempatkan suami di bawah kewajiban moral yang sama dengan istri, maka sesungguhnya Yesus telah mengangkat status dan martabat perempuan).

Jadi, bagaimanapun, bukanlah pria atau perempuan yang mengendalikan pernikahan, tetapi Tuhan Yesus sendiri yang adalah penguasa pernikahan Kristen: Apa yang dipersatukan Tuhan, tidak dapat dipisahkan oleh manusia. Pernikahan adalah Amanat Ilahi terhadap manusia sejak di taman Eden, jauh sebelum Adam dan Hawa jatuh ke dalam dosa. Tuhan pencipta adalah aktor dalam menggabungkan suami dan istri ke dalam kesatuan baru, pernikahan Kristen sejati. Dengan demikian, tidak ada manusia, sistem, situasi, penderitaan, masalah atau apa pun yang dapat memisahkan apa yang telah dipersatukan Allah.

\section{SIMPULAN}

Setelah menganalisis, mendeskripsikan, meneliti dan mempresentasi hasil penelitian literatur ini, maka patutlah disimpulkan bahwa "Perceraian Darurat Di Indonesia!" Perceraian pasangan suami - istri di Indonesia menempati peringkat pertama di Asia Pasifik dan Jawa Timur menduduki rangking satu sebagai penyumbang perceraian suami - istri terbesar di Indonesia.

Pernikahan adalah mandat Tuhan, oleh karena itu bersifat permanen. Tetapi itu tidak membatalkan atau meniadakan komitmen suami-istri dalam rumah tangga. Pernikahan Kristen bersifat monogami: satu pria dan satu perempuan, hubungan sakral antara suami dan istri yang disaksikan oleh Tuhan, gereja dan negara.

Perceraian adalah konsesi ilahi, bukan konstitusi ilahi. Tuhan adalah pemrakarsa institusi pernikahan sejak awal, sebelum manusia jatuh ke dalam dosa. Tuhan hanya menciptakan pria dan perempuan. Untuk alasan apa pun, motivasi dan tujuan Tuhan Yesus Kristus tidak pernah menginginkan perceraian antara suami dan istri Kristen di Kota Batu, Indonesia

Temuan yang menarik adalah bahwa sampai penelitian ini selesai, peneliti belum menemukan data lapangan atau statistik tentang kasus perceraian antara suami - istri Kristen di Kota Wisata Batu, Jawa Timur yang dipublikasi atau terdata di Kantor Pengadilan atau yang terdaftar sebagai anggota gereja di Kota Wisata Batu. Sangat

${ }^{9}$ Matius, menulis untuk orang-orang Yahudi, menghilangkan ay. 12; tetapi Markus, yang menulis untuk orang Romawi, memasukkan ayat itu. 
menggembirakan untuk diselidiki, apakah karena suami dan istri telah memahami dengan benar sifat pernikahan Kristen sehingga tidak bercerai? Apa pun alasannya, suami dan istri Kristen harus memahami tanggapan Yesus Kristus terhadap perceraian sebagai landasan konseptual dalam menanggapi ancaman perceraian.

Hasil penelitian dan temuan lapangan menjelaskan bahwa ada dua kasus perceraian Kristen, tetapi tidak dicatat pada Kantor Pemerintah Kota Wisata Batu. Hal ini mendorong peneliti lain untuk melakukan penelitian lebih lanjut, mengapa hanya dua kasus perceraian dalam sepuluh tahun terakhir di Kota Wisata Batu?

\section{REKOMENDASI}

Pernikahan adalah Amanat Tuhan, maka untuk menjaganya agar terhindar dari perceraian maka peneliti merekomendasi beberapa pokok penting.

Pertama, Kementerian Agama Kota Wisata Batu, Jawa Timur hendaknya memiliki program dan konsisten melakukan edukasi kepada calon pengantin agar menjadi keluarga yang rukun dan kuat untuk melahirkan generasi emas bagi bangsa dan negara; Kedua, Lembaga-lembaga Keagamaan mengadakan paket Pendidikan Khusus Pranikah selama minimal enam bulan kepada calon pengantin; Ketiga, Ceramah-ceramah mengenai sakralnya suatu ikatan pernikahan disampaikan dan disosialisasikan oleh Pemerintah dan atau Tokoh Agama di tempat-tempat Ibadah maupun di kelurahan-kelurahan di Kota Wisata Batu; Keempat, Tokoh-tokoh Agama sesuai agama penganut pasangan pernikahan, hendaknya melakukan pendampingan dan pembinaan pasangan yang sedang berkonflik; Kelima, Melihat, mencermati, dan menganalisis tingginya angka perceraian di Jawa Timur, maka sudah waktunya Pemerintah Kota Wisata Batu menerapkan sistem denda berupa uang kepada pasangan yang bercerai. Besar atau kecilnya nominal denda tersebut disesuaikan dengan lamanya masa pernikahan. Semakin cepat masa perceraian maka semakin besar denda yang harus dibayar oleh pasangan tersebut kepada Pemerintah. Artinya denda kepada pasangan yang sudah menikah selama 20 tahun dendanya akan lebih kecil dibandingkan dengan perceraian pasangan yang menikah 5 tahun. Semoga semua saran oleh peneliti berguna bagi instansi terkait sehingga dapat menekan angka perceraian yang tercatat di Kantor Pemerintah maupun tidak terdata di Kota Wisata Batu, Jawa Timur.

\section{DAFTAR PUSTAKA}

Alexander, J.A. 1986. Mark: The Geneva Series of Commentaries. Pennsylvania: The Banner of Truth Trust.

Edwards, James R. 2002. The Gospel According To Mark. Grand Rapids, Michigan: William B. Eerdmans.

Evans, Craig A. 2001. Word Biblical Commentary: Mark 8:27-16:20. Nashville: Thomas Nelson Publishers.

Boring, M. Eugene. 2006. Mark: A Commentary. Louisville, Kentucky: Westminster John Knox Press.

Emil, Schurer. 1973. A History of the Jewish People In The Time of Jesus Christ. New York: Hendrickson.

Gaebelein, Frank E. (Gen. Ed.). 1984. The Expositors Bible Commentary. Vol. 8. Grand Rapids, Michigan: Zondervan Publishing House.

Gundry, Robert Horton. 1992. Mark: A Commentary on His Apology for the Cross. Grand Rapids, Michigan: William B. Eerdmans Publishing Company.

Hooker, Morna D. 2009. The Gospel according to Saint Mark. Cambridge: Baker Academic.

Lane, W.L. 1974. The Gospel according to Mark. Grand Rapids: Eerdmans. 
Manson, T.W. 1951. The Teaching of Jesus. Cambridge: Cambridge University Press.

Murray, J. 1974. Divorce. Philadelphia: Presbyterian and Reformed.

Prawirohamidjojo, R. Soetojo dan Safioedin Aziz, 1986. Law on People and Families. Bandung: Alumni.

Simanjuntak, P.N.H. 2007. Principles of Indonesian Civil Law. Jakarta: Library Djambat.

Subekti, 1985. Principles of Civil Law. Jakarta: Intermasa.

Syaifuddin, Muhammad. 2013. Divorce Law. Jakarta: Sinar Grafika.

Taylor, V. 1966. The Gospel according to St. Mark. London: Macmillan/New York: St. Martin's.

Wright, H. Norman. 2010. So You're Getting Married. Terj. Yogyakarta: Gloria. 